\title{
THE EFFECT OF METHYLPHENIDATE HYDROCHLORIDE COMBINED WITH PLATYCLADI SEED EXTRACT ON ATTENTION DEFICIT HYPERACTIVITY DISORDER IN A MURINE MODEL
}

\author{
JINHUA ZHAO ${ }^{1,2}$, JIHONG TANG $^{1 *}$, XIAOYAN SHI $^{1}$ \\ ${ }^{I}$ Department of Neurology, Children's Hospital Affiliated to Soochow University, Suzhou, 215025, Jiangsu, China \\ ${ }^{2}$ Department of Pediatrics, Nantong First People's Hospital, Nantong, 226001, Jiangsu, China
}

*corresponding author: tangjihongsoohow@163.com

Manuscript received: November 2020

\begin{abstract}
The study aimed to evaluate the therapeutic effect and the underlying mechanism of methylphenidate hydrochloride combined with Platycladi seed extract on attention deficit hyperactivity disorder (ADHD) in a murine model. Forty-eight SPF male SHR rats were divided into 4 groups as follows: a rat model of attention deficit hyperactivity disorder that received $10 \mathrm{~mL} / \mathrm{kg}$ bw/day saline solution, a methylphenidate hydrochloride group treated with $3.75 \mathrm{mg} / \mathrm{kg}$ bw/day methylphenidate hydrochloride, a Platycladi seed extract group treated with $9 \mathrm{mg} / \mathrm{kg}$ bw/day Platycladi seed extract, a methylphenidate hydrochloride (MHCRT) combined with Platycladi seed extract group treated with $3.75 \mathrm{mg} / \mathrm{kg}$ bw MHCRT plus $9 \mathrm{mg} / \mathrm{kg}$ bw/day Platycladi seed extract. Twelve Wistar Kyoto rats were used as a normal group that received $10 \mathrm{~mL} / \mathrm{kg}$ bw/day saline solution. After 14 days of treatment the combination of MHCRT and Platycladi seed extract significantly reduced the serum NE (norepinephrine) level in rats and significantly increased the DA (dopamine) and 5-HT (serotonin) levels along with improving neurobehavioral changes related with ADHD with a superior effect compared with the use of Platycladi seed extract or MHCRT alone. Regarding the protein expression level in brain tissue when associated to the standard treatment with MHCRT, Platycladi seed extract additively increased the effect of MHCRT and succeeded to significantly increase the expression of GIT1 (ARF GTPaseactivating protein), CDH13 (cadherin 13), BDNF (brain-derived neurotrophic factor), CaM (calmodulin) and NET (adrenergic transporters) and significantly decreased the expression of LPHN3 (latrophilin 3) compared with the model group. In serum, the association of Platycladi seed extract with MHCRT additively increased the effect of MHCRT alone on increasing the protein level of $\beta$-EP (betaendorphin), IP3 (inositol triphosphate) and Glu (Glutamine synthetase) and decreased PG (plakoglobin) level compared with the model group. In conclusion, Platycladi seed extract can potentiate the effect of standard MHCRT treatment by regulating the expression of neurotransmitters in an ADHD murine model.
\end{abstract}

\section{Rezumat}

Studiul a urmărit evaluarea efectului terapeutic și mecanismul ce stă la baza acțiunii clorhidratului de metilfenidat, combinat cu extractul din semințe de Platycladi, asupra unui model murin de hiperactivitate cu deficit de atenție (ADHD). Patruzeci și opt de șobolani masculi SPF spontan hipertensivi (SHR) au fost împărțiți în 4 grupuri după cum urmează: un grup de șobolani cu ADHD care a primit $10 \mathrm{~mL} / \mathrm{kgc} / \mathrm{zi}$ ser fiziologic, un grup de şobolani care a primit $3,75 \mathrm{mg} / \mathrm{kgc} / \mathrm{zi}$ metilfenidat, un grup de şobolani care a primit $9 \mathrm{mg} / \mathrm{kgc} / \mathrm{zi}$ extract de semințe de Platycladi, un grup tratat cu $9 \mathrm{mg} / \mathrm{kg}$ corp/extract de semințe de Platycladi și $3,75 \mathrm{mg} / \mathrm{kgc}$ metilfenidat (MHCRT). Doisprezece şobolani Wistar Kyoto au fost folosiţi ca şi grup normal care a primit $10 \mathrm{~mL} / \mathrm{kgc} / \mathrm{zi} \mathrm{ser}$ fiziologic. După 14 zile de tratament, combinația utilizată a redus semnificativ nivelul seric de NE (norepinefrină) la şobolani şi a crescut semnificativ nivelurile de DA (dopamină) şi 5-HT (serotonină), împreună cu îmbunătăţirea modificărilor neurocomportamentale legate de ADHD, având efect superior comparativ cu utilizarea singulară a extractului de semințe Platycladi sau a metilfenidatului. În ceea ce privește nivelul de exprimare a proteinelor în țesutul cerebral, atunci când este asociat tratamentului standard cu MHCRT, extractul de semințe de Platycladi a crescut suplimentar efectul MHCRT și a reuşit să crească semnificativ expresia proteinelor GIT1, CDH13 (cadherin 13), BDNF (factor neurotrofic derivat din creier), CaM (calmodulină) și NET (transportori adrenergici) și a scăzut semnificativ expresia LPHN3 (latrofilina 3). În concluzie, extractul de semințe Platycladi poate potența efectul tratamentului cu metilfenidat prin reglarea expresiei neurotransmițătorilor într-un model murin de ADHD.

Keywords: methylphenidate hydrochloride, Platycladi seed extract, ADHD, neurotransmitters

\section{Introduction}

Attention deficit hyperactivity disorder (ADHD), is a behavioural disorder that affects mainly children, being very common in those with age between 4 and 17 years old [1]. It is one of the most common neurodevelopmental disorders in children. ADHD occurs in early childhood, is diagnosed in school age and usually lasts until adulthood [2]. Children with ADHD are easily distracted, unable to concentrate, fidgety and unable to wait [3]. The main symptoms of ADHD include personality impulses, lack of concentration and over-activity. These symptoms may lead to their poor performance in school, shame and other psychological problems. The incidence rate is $5 \%$, 
and the incidence of boys is higher than that of girls and the incidence rate of male and female is 3:1 10:1 [4]. Many parents can't find the disease in time, so children with ADHD can't get effective treatment in time. Therefore, it is of great interest in the clinic to discover more medicine appropriate for this disease as currently there are only limited drugs that showed beneficial effects in the treatment of ADHD. Methylphenidate hydrochloride is a central nervous stimulant [5]. The mechanism of its action in the treatment of ADHD is not clear. It is believed that the drug blocks the reuptake of norepinephrine and dopamine in the presynaptic neurons, and increases the release of these monoamines to the outer neuronal space. [6].

Dry seeds of Platycladus orientalis [L.] Franco (Crupressaceae Family) have been used in the traditional Chinese medicine for their beneficial effects in bronchitis, amnesia, asthma, constipation, insomnia, ameliorate cognitive deficits [7].

In this study we aimed to evaluate the beneficial effect of using platyclade seed extract along with the standard treatment with methylphenidate for the treatment of attention deficit hyperactivity disorder in a murine model.

\section{Materials and Methods}

\section{Animals}

Forty-eight Specified Pathogen Free (SPF) male spontaneously hypertensive rats (SHR) and 12 Wistar Kyoto (WKY) male rats, 3 weeks old, weighing (61 \pm $5 \mathrm{~g}$ ), were purchased from Yisen Experimental Animal Technology Co., Ltd., China. The animals were acclimatized to the new conditions for one week with free access to feed and water before the experiment. The animal experiment was approved by the Ethical Committee of Children's Hospital Affiliated to Soochow University, China.

\section{ADHD animal model}

Spontaneously hypertensive rats (SHR) were isolated from Wistar Kyoto rats by selective inbreeding. SHR has become the most widely used ADHD animal model because of its great similarity in behaviour, neurobiology and metabolic state with clinical ADHD patients. SHR presents typical ADHD symptoms at 4 - 10 weeks of age, which does not need drug induction [8]. Therefore, the exposure of animals to the treatment started at 4 weeks old.

The forty-eight SHR rats were randomly divided into the model group, methylphenidate hydrochloride (MHCRT) group, Platycladi seed extract group and MHCRT+Platycladi seed extract group, with 12 animals per group. Besides, 12 Wistar Kyoto (WKY) rats were used as the normal group.

The animals from the model group and the control group received by gavage $10 \mathrm{~mL} / \mathrm{kg}$ bw/day saline solution (ThermoFisher, USA). The animals from MHCRT group received $3.75 \mathrm{mg} / \mathrm{kg}$ bw/day methyl- phenidate hydrochloride (Sigma Aldrich, USA). The animals from Platycladi seed extract group received 9 $\mathrm{mg} / \mathrm{kg}$ bw/day Platycladi seed extract (Ruikang biology, China). The animals from MHCRT+ Platycladi seed extract group received $3.75 \mathrm{mg} / \mathrm{kg}$ per day methylphenidate hydrochloride plus 9 $\mathrm{mg} / \mathrm{kg}$ bw per day Platycladi seed extract. The treatment lasted for 14 days.

Behavioural evaluation

Forced swimming test: The animals have been put into a glass tank $(50 \mathrm{~cm} \times 30 \mathrm{~cm} \times 60 \mathrm{~cm})$ with a water temperature of $25 \pm 1{ }^{\circ} \mathrm{C}$ and a water depth of $30 \mathrm{~cm}$. The swimming time and crawling time within $5 \mathrm{~min}$ was video recorded (if there is no movement, the test was stopped immediately). The test was performed $1 \mathrm{~h}$ after the $3^{\text {rd }}, 8^{\text {th }}$ and $13^{\text {th }}$ doses, and the average value was taken as the score.

Behaviours evaluation: Immobility - the rat is floating in the water and struggling, and it only makes the necessary movements to keep the head above the water, or touch the bottom of the pool for more than 1 second as the standard; swimming - the rat has an active swimming action, not just keeping the head above the surface of the water, such as swimming around a glass tank; climbing - vigorous exercise accompanied by constant front paws in and out of the water, the body is often erected against the tank wall.

Assessment of ADHD symptoms: Each rat was put into a glass jar $(50 \mathrm{~cm} \times 30 \mathrm{~cm} \times 60 \mathrm{~cm})$ and the stereotype behaviours were recorded and scored by video and the social behaviours were investigated. The evaluation was conducted every $30 \mathrm{~min}$, and the score was the sum of 4 evaluation scores within 2 hours. One hour after the fourth, ninth and fourteenth administration, the test was carried out respectively, and the average value of the three times was taken as the score.

Stereotypical behaviour rating criteria and social behaviour evaluation content: 0 points - stand still, with low or no activity; 1 point - normal activity, occasionally forward movement; 2 points - the active partner repeatedly explores forward, the rat turns in a circle around the cage with a stereotyped behaviour, no other behaviour; 3 points - continuous forward exploration; 4 points - repeated head up, shaking or rotation; 5 points - rapid head shaking, turning or backabdominal movement of the head. Social behaviour refers to the behaviour of rats to explore the new environment, including non-stop sniffing, movement in new areas of the environment, and regular raising of forelimbs to look around and contact with strange rats around.

Step Sequence: The researcher fixes the back half of the rat's body and hind-limbs with one hand to keep it off the ground, and fixes one forelimb with the other hand and places the other forelimb on the ground and record the number of steps that touch and leave the forelimb on the ground side of the rat 
while moving, and measure the number of steps on both sides of the forelimb alternately. The test was performed 1 hour after the $5^{\text {th }}, 19^{\text {th }}$ and $15^{\text {th }}$ doses, and the average value was taken as the score.

Number of spontaneous activity of rats after modelling The autonomous activity data of the monitored animals on a period of 12 hours (20:00 - 8:00) were extracted from the video system that supervised the animals. The animals were sacrificed on the $15^{\text {th }}$ day after treatment around $8 \mathrm{am}$. Before sacrification, the animals were fasted for $12 \mathrm{~h}$. The rats were anaesthetized by intraperitoneal injection with $10 \mathrm{~g} / \mathrm{L}$ chloral hydrate (ThermoFisher, USA), $3 \mathrm{~mL}$ of blood were collected from the orbit, and then the animals were sacrificed by decapitation. The brain and hippocampus were quickly separated on an ice table. The specimens were weighed and wrapped in thin foil. The blood was centrifuged at $3000 \mathrm{r} / \mathrm{min}$ for $10 \mathrm{~min}$, and then the supernatant was collected. The brain tissue and supernatant were stored in a refrigerator at $-70^{\circ} \mathrm{C}$ till further analysis.

The determination of norepinephrine (NE), dopamine (DA) and serotonin (5-HT) by High Performance Liquid Chromatography (HPLC)

The levels of norepinephrine (NE), dopamine (DA) and serotonin (5-HT) in serum and hippocampus were detected by HPLC (High Performance Liquid Chromatography) method (Waters, USA).

Western blot assay

Parts of the brain were homogenized with phosphate buffer saline (PBS) at a concentration of $10 \%$, and $10 \mathrm{mg}$ were added to 100 RIPA Lysis Buffer (ThermoFisher, USA). The samples were incubated on ice for 20 minutes, centrifuged at $13000 \mathrm{rot} / \mathrm{min}$ for 20 minutes, and then the supernatant was collected. The concentration of extracted protein was determined by Bicinchoninic acid method (ThermoFisher, USA).

The $1 \times$ SDS gel buffer was added to normalize the protein concentration of each group. The protein samples were diluted with $5 \times$ loading buffer and PBS, boiled in a boiling water bath for $5 \mathrm{~min}$ and denatured. The protein liquid after denaturation was added to $12 \%$ SDS-PAGE gel (ThermoFisher, USA) and $80 \mathrm{~V}$ constant pressure electrophoresis for 60 120 min. The SDS-PAGE glue (ThermoFisher, USA) was placed on the nitrocellulose membrane to carry out the constant current transfer. $3 \%$ bovine serum albumin (BSA), (ThermoFisher, USA) was used for $4^{\circ} \mathrm{C}$ closure. After closure, the nitrocellulose membrane was washed with PBS and incubated for $45 \mathrm{~min}$ at room temperature with the primary antibody antiGIT1 (ARF GTPase-activating protein) (1:5000), anti-

CDH13 (cadherin 13) (1:5000), anti-LPHN3 (latrophilin 3) (1:5000), anti-BDNF (brain-derived neurotrophic factor) (1:5000), anti-CaM (calmodulin) (1:5000), anti-NET (adrenergic transporters) (1:5000) and antiGAPDH (glyceraldehyde 3-phosphate dehydrogenase) (1:5000) (Abcam, USA) for tissues and anti- $\beta$-EP (betaendorphin) (1:5000), anti-PG (plakoglobin) (1:5000), anti-IP3 (inositol triphosphate) (1:5000), anti-Glu (Glutamine synthetase) (1:5000), and anti-GAPDH (1:5000) (Abcam, USA) for serum. Then the nitrocellulose membrane was washed with PBS buffer, and incubated with the second antibody labelled with horseradish peroxidase (Abcam, USA) (1:1000) at room temperature for 30 minutes. Then, the membrane was washed with PBS buffer and the ECL chemiluminescence agent (ThermoFisher, USA) was used. Kodak X (Eastman Kodak Company, USA) was used to expose the nitrocellulose membrane for about three minutes. The X-ray film was scanned (Eastman Kodak Company, USA), and the gray analysis of the strip was processed by Gel-Pro Analyzer software (Media Cybernetics, USA). The gray value of each band was measured by software in three independent repeated experiments, and the ratio of the gray value of the target gene product to that of the GAPDH product (glyceraldehyde-3-phosphate dehydrogenase) was used as the relative expression of the protein.

Statistical analysis

The data were analysed by Origin8.0 software (IBM, USA). Results that met the normal distribution and variance homogeneity were analysed by One way ANOVA or Student's t-test. A value of $p<0.05$ was considered statistically significant.

\section{Results and Discussion}

\section{ADHD animal model}

Compared with the normal group, the number of horizontal exercises and vertical exercises of the model group increased significantly. It can be seen that the rats with ADHD were successfully modelled (Table I). Effect of the treatment on neurotransmitters levels in rat brain tissue

The combination of MHCRT and Platycladi seed extract can significantly reduce the NE level in the hippocampus of the rat brain, and increase the DA and 5-HT level compared with the model group ( $\mathrm{p}<$ 0.001 ), and the combined effect of the two drugs is significantly higher than that of the MHCRT alone $(\mathrm{p}<0.05)$ (Table II). The Platycladi seed extract alone succeeded only to significantly increase the DA level compared with the model group $(\mathrm{p}<0.05)$ (Table II).

Table I

Number of spontaneous activity of rats after modelling

\begin{tabular}{cccc}
\hline \multicolumn{1}{c}{ Group } & Numbers & Number of horizontal movements & Number of vertical movements \\
\hline Normal group & 12 & $63.7 \pm 11.7$ & $60.1 \pm 18.4$ \\
Model group & 12 & $86.4 \pm 15.3^{*}$ & $132.4 \pm 23.6^{*}$ \\
\hline & $p<0.05$ compared with the normal group & &
\end{tabular}


Comparison of neurotransmitter level in the hippocampus of each group

\begin{tabular}{|c|c|c|c|c|}
\hline Group & Numbers & 5-HT $(\mu \mathrm{g} / \mathrm{g})$ & NE $(\mu \mathrm{g} / \mathrm{g})$ & DA $(\mu \mathrm{g} / \mathrm{g})$ \\
\hline Normal group & 12 & $1.84 \pm 0.32$ & $2.12 \pm 0.45$ & $8.56 \pm 0.78$ \\
\hline Model group & 12 & $0.99 \pm 0.16^{* *}$ & $3.56 \pm 0.78^{* *}$ & $6.67 \pm 0.56^{* *}$ \\
\hline MHCRT group & 12 & $1.34 \pm 0.19^{* *, \$ \$}$ & $2.89 \pm 0.17^{* *, \$}$ & $7.59 \pm 0.65^{*, \$}$ \\
\hline Platycladi seed extract group & 12 & $1.13 \pm 0.22^{* *}$ & $3.24 \pm 0.24^{* *}$ & $7.05 \pm 0.21^{* *, \$}$ \\
\hline MHCRT+Platycladi seed extract group & 12 & $1.56 \pm 0.24^{*, \$ \$, \#, \&}$ & $2.56 \pm 0.45^{*, \$ \$, \#, \& \&}$ & $8.04 \pm 0.34^{*, \$ \$, \#, \& \&}$ \\
\hline
\end{tabular}

${ }^{*} \mathrm{p}<0.05$ compared with normal group; ${ }^{* *} \mathrm{p}<0.001$ compared with normal group; ${ }^{\$} \mathrm{p}<0.05$ compared with the model group;

$\$ \$ p<0.001$ compared with the model group; ${ }^{\#} \mathrm{p}<0.05$ compared with MHCRT group; ${ }^{\&} \mathrm{p}<0.05$ compared with Platycladi seed extract group; ${ }^{\& \&} \mathrm{p}<0.001$ compared with Platycladi seed extract group

Effect of Platycladi Seed extract Group on neurotransmitter content in SHR rat serum

The combination of MHCRT and Platycladi seed extract significantly reduced the NE levels in the serum, and increased the DA and 5-HT levels compared with the model group $(\mathrm{p}<0.001)$, and the combined effect of the two drugs was significantly higher than that of the MHCRT alone ( $p<0.001$ for 5-HT and $\mathrm{p}<0.05$ for DA and NE) (Table III). The Platycladi seed extract alone succeeded only to significantly increase the 5HT level compared with the model group $(\mathrm{p}<0.001)$ (Table III).

The results in Table III show that MHCRT group and Platycladi seed extract group had a significantly reduced NE content in rat serum, increased DA and 5-HT levels ( $\mathrm{p}<0.05$ or $\mathrm{p}<0.01$ ), and the combination of the two active ingredients is significantly better than the single drug.

Table III

Comparison of neurotransmitters levels in the serum of each group

\begin{tabular}{lcccc}
\hline \multicolumn{1}{c}{ Group } & Numbers & 5-HT $(\mu \mathrm{g} / \mathrm{mL})$ & NE $(\mu \mathrm{g} / \mathrm{mL})$ & DA $(\mu \mathrm{g} / \mathrm{mL})$ \\
\hline Normal group & 12 & $1.49 \pm 0.33$ & $1.11 \pm 0.34$ & $1.23 \pm 0.25$ \\
Model group & 12 & $0.23 \pm 0.13^{* * *}$ & $2.23 \pm 0.42^{* *}$ & $0.53 \pm 0.14^{* * *}$ \\
MHCRT group & 12 & $0.76 \pm 0.24^{* *, \$ \$}$ & $1.83 \pm 0.28^{* *, \$}$ & $0.79 \pm 0.16^{* *, \$ \$}$ \\
Platycladi seed extract group & 12 & $0.54 \pm 0.13^{* *, \$ \$, \#}$ & $2.02 \pm 0.13^{* *, \#}$ & $0.65 \pm 0.27^{* * *}$ \\
MHCRT+Platycladi seed extract group & 12 & $1.23 \pm 0.09^{*, \$ \$, \#, \& \&}$ & $1.51 \pm 0.16^{*, \$ \$, \#, \& \&}$ & $0.92 \pm 0.14^{*, \$ \$, \#, \&}$ \\
\hline
\end{tabular}

* $\mathrm{p}<0.05$ compared with normal group; ${ }^{* *} \mathrm{p}<0.001$ compared with normal group $;{ }^{\$} \mathrm{p}<0.05$ compared with the model group;

$\$ \$ p<0.001$ compared with the model group; ${ }^{\#} \mathrm{p}<0.05$ compared with MHCRT group; ${ }^{\# \#} \mathrm{p}<0.001$ compared with MHCRT group;

${ }^{\&} \mathrm{p}<0.05$ compared with Platycladi seed extract group; ${ }^{\& \&} \mathrm{p}<0.001$ compared with Platycladi seed extract group

Table IV

The influence of MHCRT and Platycladi Seed Extract on ADHD behaviour

\begin{tabular}{lcccc}
\hline \multicolumn{1}{c}{ Group } & Swimming Time & Climbing time & $\begin{array}{c}\text { Stereotyped } \\
\text { behaviour score }\end{array}$ & $\begin{array}{c}\text { Step } \\
\text { number }\end{array}$ \\
\hline Normal group & $26.4 \pm 3.4$ & $3.5 \pm 1.4$ & $10.3 \pm 2.1$ & $11.2 \pm 3.8$ \\
Model group & $64.7 \pm 11.4^{*}$ & $12.6 \pm 3.5^{*}$ & $55.6 \pm 13.5^{*}$ & $5.4 \pm 1.7^{*}$ \\
MHCRT group & $46.4 \pm 8.2^{* *, \$ \$}$ & $8.6 \pm 3.3^{* *, \$}$ & $36.4 \pm 10.2^{* *, \$ \$}$ & $7.7 \pm 3.6^{*}$ \\
Platycladi seed extract group & $55.3 \pm 9.5^{* *, \$, \#}$ & $10.5 \pm 3.7^{* *, \#}$ & $43.3 \pm 11.8^{* *, \$, \#}$ & $6.2 \pm 2.5^{* *}$ \\
MHCRT+Platycladi seed extract group & $36.5 \pm 7.3^{* * \$, \#, \& \&}$ & $6.8 \pm 2.7^{*, \& \&, \&}$ & $26.6 \pm 8.88^{* *, \$, \#, \& \&}$ & $8.3 \pm 3.1^{\$}$ \\
\hline
\end{tabular}

$\mathrm{p}<0.05$ compared with normal group; ${ }^{* *} \mathrm{p}<0.001$ compared with normal group; ${ }^{\$} \mathrm{p}<0.05$ compared with the model group;

${ }^{\$ \$} \mathrm{p}<0.001$ compared with the model group; ${ }^{\#} \mathrm{p}<0.05$ compared with MHCRT group; ${ }^{\# \#} \mathrm{p}<0.001$ compared with MHCRT group;

$\& \mathrm{p}<0.05$ compared with Platycladi seed extract group; ${ }^{\&} \mathrm{p}<0.001$ compared with Platycladi seed extract group

Effects of Platycladi seed extract on swimming time, ADHD score and limb motor function in rats Compared with the normal group, the swimming time and climbing time of rats in the model group were significantly increased $(\mathrm{p}<0.001)$. The treatment with the combination of MHCRT+Platycladi seed extract significantly decreased the swimming time and climbing time of the animals $(\mathrm{p}<0.001)$ and the effect was increased compared with MHCRT alone $(\mathrm{p}<0.05)$ and Platycladi seed extract alone ( $<<0.001)$ (Table IV). Compared with the normal group, the stereotyped behaviour of the model group was significantly increased $(\mathrm{p}<0.001)$. The treatment with the combination of MHCRT+Platycladi seed extract significantly decreased $(\mathrm{p}<0.001)$ the behavioural symptoms and the effect was higher compared with MHCRT alone $(\mathrm{p}<0.05)$ and Platycladi seed extract alone $(\mathrm{p}<0.001)$ (Tabel IV). Regarding the limb motor function translated by the step number, the model group showed a significantly decrease in the number of steps compared with the normal group ( $\mathrm{p}<0.001$ ), weakened. The combination of Platycladi seed extract and MHCRT succeeded to significantly improve the limb motor function compared with the model group ( $\mathrm{p}<0.05)$ (Table IV).

Effect of Platycladi seed extract on the activity frequency of rats

Compared with the normal group, the number of horizontal and vertical movements in the model group 
increased significantly. For the number of horizontal movements only the combined treatment with MHCRT and Platycladi seed extract succeeded to significantly decrease them compared with the model group $(\mathrm{p}<$ 0.001). The treatment with MHCRT alone and combined with Platycladi seed extract succeeded to significantly decrease the number of vertical movements compared with the model group, the effect being by superior for the treatment with MHCRT alone ( $<$ < 0.001) (Table V). Expression of GIT1, CDH13, LPHN3, BDNF, CaM and NET in rat brain

Western blot results showed that, in brain tissues, the expression of GIT1, CDH13, BDNF, CaM and NET in the model group was significantly decreased compared with the normal group, while the expression of LPHN3 was significantly increased compared with the normal group ( $\mathrm{p}<0.001)$. After treatment, in both MHCRT and Platycladi seed extract groups the expression of GIT1 and NET protein $(\mathrm{p}<0.05)$ increased, and the combined effect of the two agents was higher than that of single drug $(\mathrm{p}<0.001)$. Only the MHCRT treatment and MHCRT plus Platycladi seed extract can increase the expression of CDH13, BDNF and CaM, while Platycladi seed extract alone had no significant effect on their expression $(p<0.05)$ (Figure 1).

Table V

The number of spontaneous activity of rats after administration

\begin{tabular}{lccc}
\hline \multicolumn{1}{c}{ Group } & Numbers & Number of horizontal motions & Number of vertical motions \\
\hline Normal group & 12 & $56.6 \pm 8.3$ & $67.3 \pm 11.8$ \\
Model group & 12 & $85.4 \pm 15.8^{* *}$ & $122.4 \pm 27.3^{* * *}$ \\
MHCRT group & 12 & $73.2 \pm 10.9^{* *}$ & $78.6 \pm 13.3^{*, \$ \$}$ \\
Platycladi seed extract group & 12 & $76.5 \pm 12.3^{* *}$ & $97.5 \pm 18.7^{* *, \&, \#}$ \\
MHCRT+Platycladi seed extract group & 12 & $70.3 \pm 7.9^{* *, \$}$ & $87.4 \pm 15.3^{*, \$ \$}$ \\
\hline
\end{tabular}

${ }^{*} \mathrm{p}<0.05$ compared with normal group; ${ }^{* *} \mathrm{p}<0.001$ compared with normal group $;{ }^{\$ \$} \mathrm{p}<0.001$ compared with the model group;

${ }^{\#} \mathrm{p}<0.05$ compared with MHCRT group; ${ }^{\&} \mathrm{p}<0.05$ compared with Platycladi seed extract group

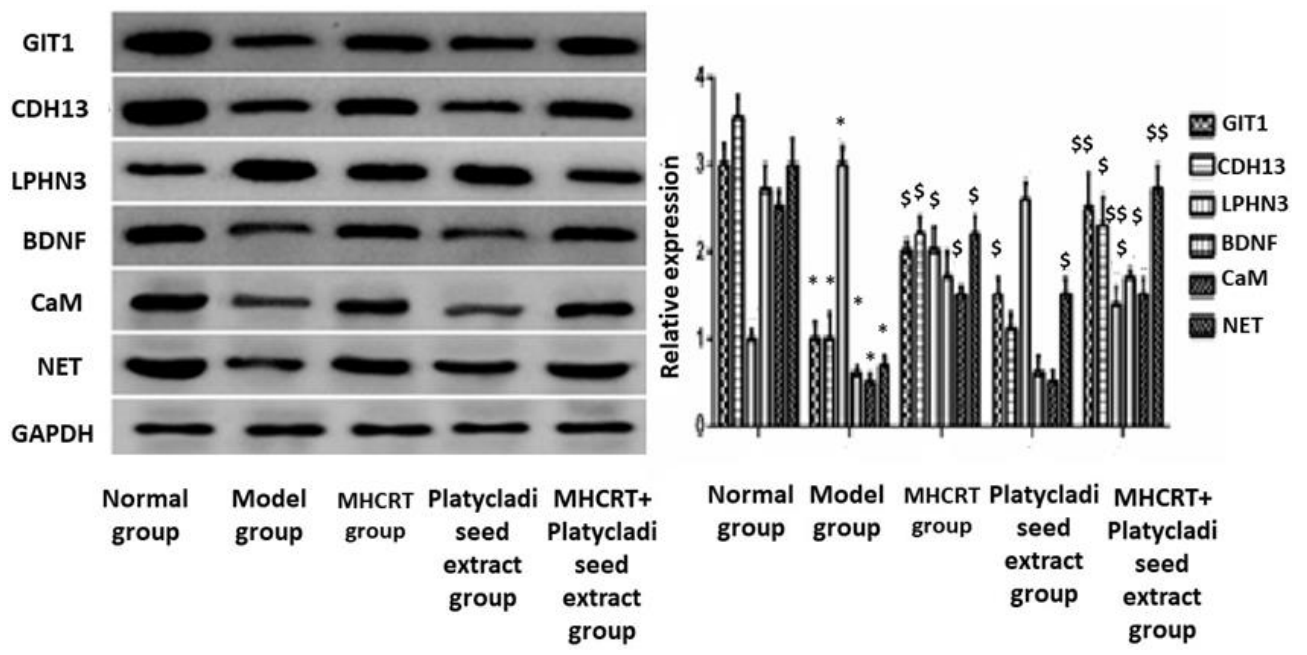

Figure 1.

The expression levels of GIT1, CDH13, LPHN3, BDNF, CaM and NET in rat brain tissues

$* \mathrm{p}<0.001$ compared with normal group; ${ }^{\$} \mathrm{p}<0.05$ compared with normal group; ${ }^{\$ \$} \mathrm{p}<0.001$ compared with the model group

Expression of $\beta-E P, P G, I P 3$ and $G L u$ in rat serum Western blot results showed that in the model group the expression of $\beta$-EPT, IP3 and GLu in the serum was significantly decreased compared with the normal group, while the expression intensity of PG was significantly increased compared with the normal group ( $\mathrm{p}<0.001$ ) (Figure 2). After treatment, both MHCRT and Platycladi seed extract determined a significant increase in the levels of IP3 and GLu proteins ( $\mathrm{p}<0.05)$, and the combined effect of the two was superior compared with the single drug $(\mathrm{p}<0.001)$. However, only the MHCRT and MHCRT+Platycladi seed extract treatments succeeded to significantly increase the expression of $\beta$-EP proteins and significantly decreased the expression of PG proteins ( $\mathrm{p}<0.05)$ (Figure 2). 


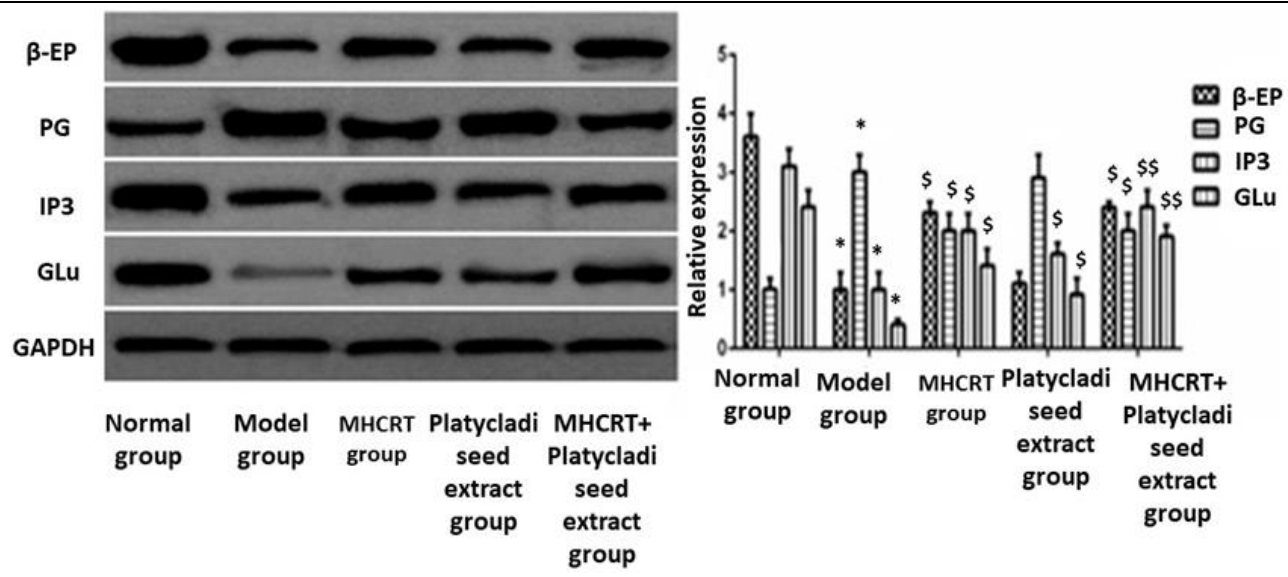

Figure 2.

The expression of $\beta$-EP, PG, IP3 and GLu proteins in the serum

$* \mathrm{p}<0.001$ compared with normal group; ${ }^{\$} \mathrm{p}<0.05$ compared with normal group; ${ }^{\$ \$} \mathrm{p}<0.001$ compared with the model group

Methylphenidate hydrochloride is a central stimulant, that is recommended by the United States Food and Drug Administration (FDA) for the treatment of ADHD [9]. It has a history of more than 50 years and is still the first option for the clinical treatment of ADHD. Its main mechanism is to block the reuptake of mono-amine neurotransmitters, such as noradrenaline and dopamine, into presynaptic neurons, promotes the release of monoamine neurotransmitters and increases the concentration of dopamine and noradrenaline in the synaptic space. Methylphenidate has been shown to improve the excitability of the awakening centre of children, and improve the attention and self-control ability, having an important role in improving the corresponding symptoms associated with ADHD [9]. Cypress is the dry seed of Platycladus orientalis (L.) Franco, which is mainly produced in Shandong, Henan and other places in Asia. It has the effects of nourishing the heart and calming the nerves, moisturizing the intestines and laxative. It is generally used raw or in creams. The main ingredients are unsaturated fatty acids that represent almost $82 \%$ of the total fatty oil, of which linolenic acid and arachidonic acid represent the majority. In addition, it also contains Baiziren saponins, carrot glycosides, $\beta$-sitosterol, Baiziren diol, Korean pine lactone etc. [10]. Studies have found that Baiziren total terpenoids have a sedative and hypnotic effect on mice, and Baiziren total terpenes can reduce the spontaneous activity of mice, prolong the sleep time of mice induced by sodium pentobarbital, and increase the number of mice sleep cycles [11].

Biochemical studies on ADHD have shown that the monoamine neurotransmitters norepinephrine (NE), dopamine (DA) and serotonin (5-HT) play an important role in in regulation of the brain functions, and they mainly modulate the interaction between individual behaviour and the environment $[8,16]$. Therefore, measuring these monoamine neurotransmitters can help understanding the characteristics of their synthesis, release and transfer into the brain, and it is an important means in exploring the mechanisms implicated in ADHD development. The imbalance in the synthesis and expression of these neurotransmitters is related to the pathogenesis of ADHD [11]. The results of our study show that the combination of MHCRT and Platycladi seed extract can significantly reduce the serum NE level in rats and significantly increase the DA and 5-HT levels with a superior effect compared with the use of Platycladi seed extract or MHCRT alone.

Studies have found that a single nucleotide polymorphisms change in an intron of the GIT1 gene causes a decrease in GIT1 expression and is strongly associated with ADHD [12]. GIT1-deficient mice show phenotypes similar to ADHD, such as hyperactivity, decreased learning and memory abilities [12]. LPHN3 is a G protein-coupled receptor and is closely related to neural development. As a synaptic adhesion molecule, it participates in the interaction between synaptic cells, axon guidance, synapse formation and the regulation of synaptic plasticity and is important for the regulation of neuronal activity [13]. Cadherin-13 (CDH13) gene has been associated with an increase of ADHD development. Studies showed that CDH13(-/-) mice presents learning and memory problems [14]. Plakoglobin (PG), a paralog of catenin, plays a vital role in the cell-cell adhesion regulation [15]. Due to the diversity of physiological and pathological effects of organisms, cell signal transduction pathways also present intricately connected pathways. IP3 and Ca$\mathrm{CaM}$ pathways are important transduction mechanisms in the central nervous system. When hormones, neurotransmitters and corresponding receptors are activated, phospholipase $\mathrm{C}$ is activated through $\mathrm{G}$ protein mediation and the second messenger IP3 is generated. After IP3 enters the cell, it influences the intracellular Ca pathway, and then triggers a series of biological effects in the cell related with the ADHD appearance [17, 18]. BDNF gene has been shown to play a significant 
role in the pathways involved in the proliferation of dopaminergic neuronal cells [19, 20], and has been identified as one of the genes associated with the occurrence of ADHD [21]. Studies that evaluated the implication of several gene polymorphisms in ADHD development showed that NET1 gene polymorphism is associated with ADHD [22].

$\beta$-endorphin levels have been positively associated with reward cognition, response to stress, homeostasis and behavioural stability [23]. Glutamine synthetase converts glutamate into glutamine. Studies on adults with ADHD showed that the levels of glutamate and glutamine were significantly decreased compared with control [24].

The results of our study show that Platycladi seed extract can significantly increase the expression of GIT1 and NET proteins in brain tissue compared with the control group and significantly decrease the expression of LPHN3 protein. When associated to the standard treatment with MHCRT, Platycladi seed extract additively increased the effect of MHCRT and succeeded to significantly increase the expression of GIT1, CDH13, BDNF, CaM and NET and significantly decrease the expression of LPHN3 compared with the model group. In serum, Platycladi seed extract can increase the protein levels of IP3 and Glu. The association of Platycladi seed extract with MHCRT additively increased the effect of MHCRT alone on raising the protein level of $\beta$-EP, IP3 and Glu, whole diminishing of PG levels compared with the model group.

\section{Conclusions}

The results of our study confirmed that Platycladi seed extract can potentiate the effect of standard MHCRT treatment by regulating the expression of neurotransmitters in ADHD murine rats. The addition of Platycladi seed extract to the standard ADHD treatment with MHCRT improve ADHD rats' stereotyped behaviour, swimming and limb movement disorders and other behavioural abnormalities. The mechanism may be related with the modulation of GIT1, LPHN3, NET, IP3 and Glu protein expression. Further studies should be performed in order to confirm these effects in humans.

\section{Acknowledgement}

This work was supported by Nantong Science and Technology Bureau (JCZ19124).

\section{Conflict of interest}

The authors declare no conflict of interest.

\section{References}

1. Del-Ponte B, Anselmi L, Assunção MCF, TovoRodrigues L, Munhoz TN, Matijasevich A, Rohde LA, Santos IS, Sugar consumption and attention- deficit/hyperactivity disorder (ADHD): A birth cohort study. J Affect Disord., 2019; 243: 290-296.

2. Hirsch O, Chavanon M, Riechmann E, Christiansen H, Emotional dysregulation is a primary symptom in adult Attention-Deficit/Hyperactivity Disorder (ADHD). J Affect Disord., 2018; 232: 41-47.

3. Cortese S, Coghill D, Twenty years of research on attention-deficit/hyperactivity disorder (ADHD): looking back, looking forward. Evid Based Ment Health, 2018; 21(4): 173-176.

4. Pollak Y, Dekkers TJ, Shoham R, Huizenga HM, RiskTaking Behavior in Attention Deficit/Hyperactivity Disorder (ADHD): a Review of Potential Underlying Mechanisms and of Interventions. Curr Psychiatry Rep., 2019; 21(5): 33: 1-11.

5. Tzang RF, Chang YC, Kao KL, Huang YH, Huang HC, Wang YC, Muo CH, Wu SI, Sung FC, Stewart R, Increased risk of developing psychiatric disorders in children with attention deficit and hyperactivity disorder (ADHD) receiving sensory integration therapy: a population-based cohort study. Eur Child Adolesc Psychiatry, 2019; 28(2): 247-255.

6. Wang M, Zhao Q, Kang H, Zhu S, Attention deficit hyperactivity disorder (ADHD) in children with epilepsy. Ir J Med Sci., 2020; 189(1): 305-313.

7. Sun F, Chen H, Wang C, Yan X, Effect of semen Platycladi saponins and semen Platycladi oil on improvement of sleep. World J Integr Traditional, 2010; 5: 394-395, (available in Chinese).

8. Meneses A, Perez-Garcia G, Ponce-Lopez T, Tellez R, Gallegos-Cari A, Castillo C, Spontaneously hypertensive rat (SHR) as an animal model for ADHD: a short overview. Rev Neurosci., 2011; 22(3): 365-371.

9. Hidalgo-López C, Gómez-Álzate AM, García-Valencia J, Risk of Attention Deficit/Hyperactivity Disorder (ADHD) and Other Psychiatric Disorders in Siblings of ADHD Probands. Rev Colomb Psiquiatr (Engl Ed.), 2019; 48(1): 44-49.

10. Qian XZ, The colour pictorial handbook of the Chinese herbal, The common Chinese herbal medicine vol 1, $1^{\text {st }}$ ed. Beijing: Ren Min Wei Sheng Chu Ban She, 1996, (available in Chinese).

11. Chen Q, The Clinical and pharmacology of the Chinese patent medicine, $1^{\text {st }}$ ed. Beijing: Ren Min Wei Min Chu Ban She, 1998; 342-359, (available in Chinese).

12. Dunn GA, Nigg JT, Sullivan EL, Neuroinflammation as a risk factor for attention deficit hyperactivity disorder. Pharmacol Biochem Behav., 2019; 182: 22-34.

13. Lange M, Froc C, Grunwald H, Norton WHJ, BallyCuif L, Pharmacological analysis of zebrafish lphn3.1 morphant larvae suggests that saturated dopaminergic signaling could underlie the ADHD-like locomotor hyperactivity. Prog Neuropsychopharmacol Biol Psychiatry, 2018; 84(Pt A): 181-189.

14. Rivero O, Selten MM, Sich S, Popp S, Bacmeister L, Amendola E, Negwer M, Schubert D, Proft F, Kiser D, Schmitt AG, Gross C, Kolk SM, Strekalova T, van den Hove D, Resink TJ, Nadif Kasri N, Lesch KP, Cadherin-13, a risk gene for ADHD and comorbid disorders, impacts GABAergic function in hippocampus and cognition. Transl Psychiatry, 2015; 5(10): e655: 1-11. 
15. Aktary Z, Alaee M, Pasdar M, Beyond cell-cell adhesion: Plakoglobin and the regulation of tumorigenesis and metastasis. Oncotarget, 2017; 8(19): 32270-32291.

16. Handra C, Coman OA, Coman L, Enache T, Stoleru S, Sorescu AM, Ghiță I, Fulga I, The connection between different neurotransmitters involved in cognitive processes. Farmacia, 2019; 67(2): 193-201.

17. Mogavero F, Jager A, Glennon JC, Clock genes, ADHD and aggression. Neurosci Biobehav Rev., 2018; 91: 51-68.

18. Tripp G, Wickens JR, Neurobiology of ADHD. Neuropharmacology, 2009; 57(7-8): 579-589.

19. Hyman C, Hofer M, Barde YA, Juhasz M, Squinto $\mathrm{SP}$, Lindsay RM, BDNF is a neurotrophic factor for dopaminergic neurons of the substantia nigra. Nature, 1991; 350(6315): 230-232.

20. Ioniță R, Postu PA, Cioancă O, Mircea C, Hăncianu M, Hrițcu L, Anxiolytic and antidepressant effects of Matricaria chamomilla hydroalcoholic extract in a rat model of scopolamine. Farmacia, 2019; 67(1): 68-73.
21. Singh $P$, Network and pathway enrichment analysis of Attention Deficit/Hyperactivity Disorder candidate genes. Indian J Psychiatry, 2020; 62(4): 400-406.

22. Bobb AJ, Addington AM, Sidransky E, Gornick MC, Lerch JP, Greenstein DK, Clasen LS, Sharp WS, Inoff-Germain G, Wavrant-De Vrièze F, ArcosBurgos M, Straub RE, Hardy JA, Castellanos FX, Rapoport JL, Support for association between ADHD and two candidate genes: NET1 and DRD1. Am J Med Genet B Neuropsychiatr Genet., 2005; 134B(1): 67-72.

23. Foley KM, Kourides IA, Inturrisi CE, Kaiko RF, Zaroulis CG, Posner JB, Houde RW, Li CH, betaEndorphin: analgesic and hormonal effects in humans. Proc Natl Acad Sci USA., 1979; 76(10): 5377-5381.

24. Maltezos S, Horder J, Coghlan S, Skirrow C, O'Gorman R, Lavender TJ, Mendez MA, Mehta M, Daly E, Xenitidis K, Paliokosta E, Spain D, Pitts M, Asherson P, Lythgoe DJ, Barker GJ, Murphy DG, Glutamate/glutamine and neuronal integrity in adults with ADHD: a proton MRS study. Transl Psychiatry, 2014; 4(3): e373: 1-8. 